\title{
Jasa Hapus Akun dan Permasalahannya Ditinjau Dari Kekuatan Mengikat Perjanjian Antara Konsumen dengan Pelaku Bisnis Jasa Hapus Akun
}

\author{
Supeno $^{1 *}$, Fachruddin Razi ${ }^{2}$, Putri Anelia Anmas ${ }^{3}$ \\ ${ }^{1,2}$ Fakultas Hukum Universitas Batanghari Jambi \\ *Correspondence email: supeno@unbari.ac.id; putrianmas@gmail.com
}

\begin{abstract}
Abstrak. Cybercrime itu adalah sebagai perbuatan melanggar hukum yang memanfaatkan teknologi computer yang berbasis pada kecanggihan perkembangan teknologi internet. Dengan berkembangnya zaman, teknologi terus berinovasi untuk memenuhi segala kebutuhan yang diinginkan oleh masyarakat. Kecanggihan tekonologi ini seringkali disalahgunakan pada oknum yang tidak bertanggungjawab demi keuntungan mereka sendiri, jasa hapus akun hadir untuk mencegah terjadinya cybercrime tersebut akan tetapi masih terdapat banyak permasalahan dilihat dari kekuatan mengikat perjanjian jasa hapus akun.Tujuan dari penelitian ini adalah untuk memaparkan permasalahan kekuatan mengikat jasa hapus akun akun. dari hasil penelitian menunjukkan bahwa masih banyak permasalahan yang terjadi dalam jasa hapus akun terutama kurangnya kekuatan mengikat perjanjian yang dibuat oleh para pihak dalam transaksi hapus akun.
\end{abstract}

Kata Kunci: cyber crime; jasa hapus akun; kekuatan mengikat

\begin{abstract}
Cybercrime is an unlawful act that utilizes computer technology based on the sophistication of the development of internet technology. With the development of the times, technology continues to innovate to meet all the needs desired by the community. The sophistication of this technology is often abused on irresponsible people for their own gain, the account delete service is present to prevent the cybercrime from occurring but there are still many problems judging by the binding power of the account delete service agreement. The purpose of this research is to expose the problem of the binding power of account delete services. from the results of the study shows that there are still many problems that occur in the services of deleting accounts especially the lack of binding power of agreements made by the parties in the transaction delete the account.
\end{abstract}

Keywords: cyber crime; delete account services; Binding Power

\section{PENDAHULUAN}

Manusia hidup berdampingan dengan berbagai aksi kejahatan. Nyatanya, meski sudah ada berbagai peraturan hukum yang siap mengadili para narapidana sesuai dengan ketentuan hukum yang berlaku tidak membuat para pelaku kejahatan menjadi jera untuk berhenti melakukan aksi kejahatan tersebut. Dimana kejahatan yang mereka lakukan bisa berakibat fatal yang menyebabkan diri mereka masuk ke Lembaga permasyarakatan (LP) atau yang sering kita sebut dengan penjara. Sepengetahuan penulis masyarakat hanya fokus pada kejahatan yang nyata atau kejahatan secara langsung dimana ada korban dan terdakwa yang terlihat secara aktif. Namun masyarakat tidak terlalu peduli dan masih minim pengetahuan terhadap kejahatan yang tidak terlihat secara aktif tetapi secara pasif yakni kejahatan dunia maya (Cyber Crime).

Dengan seiring berkembangnya zaman, manusia berlomba-lomba untuk unggul dalam teknologi. Dikarenakan dengan system mereka yang telah terprogram secara otomatis dan mudah digunakan membuat masyarakat modern ini senang untuk menggunakannya. Menurut Wikipedia Teknologi adalah keseluruhan sarana untuk menyediakan barangbarang yang diperlukan bagi kehidupan dan kenyamanan hidup manusia. ${ }^{1}$ Manusia modern saat ini terlihat sangat bergantung pada kecanggihan teknologi seperti, laptop, handphone, computer, dan lain-lain sebagainya. Namun, tidak dapat dipungkiri manusia modern benar-benar bergantung pada salah satu kecanggihan teknologi yang satu ini yakni smartphone. Smartphone adalah Bahasa inggris dari ponsel cerdas, mengutip dari Wikipedia ${ }^{2}$ Ponsel cerdas adalah kelas ponsel dari ponsel dan perangkat komputasi bergerak multiguna. Mereka dibedakan dari ponsel berfitur dengan kemampuan perangkat keras yang lebih kuat dan sistem operasi seluler yang luas, yang memfasilitasi perangkat lunak yang lebih luas, internet (termasuk penelusuran web ${ }^{[1]}$ melalui broadband seluler), dan fungsi multimedia (termasuk musik, video, kamera, dan permainan), bersama fungsi-fungsi inti ponsel seperti panggilan suara dan pesan teks. Ponsel cerdas biasanya berisi sejumlah chip sirkuit terintegrasi IC logamoksida-semikonduktor (MOS), termasuk berbagai sensor yang dapat dimanfaatkan oleh perangkat lunak mereka (seperti magnetometer, sensor kedekatan, barometer, giroskop, atau akselerometer), dan dukungan protokol komunikasi nirkabel (seperti Bluetooth, Wi-Fi, atau navigasi satelit).Smartphone sangat mudah digunakan, tidak membutuhkan suatu tempat yang besar untuk menyimpannya, mudah di pegang, dan memudahkan manusia dalam

\footnotetext{
${ }^{1}$ https://id.wikipedia.org/wiki/Teknologi (diakses pada tanggal 30 Juli 2020, Pukul 13.20 WIB).

${ }^{2}$ https://id.wikipedia.org/wiki/Ponsel_cerdas (diakses pada tanggal 04 Agustus 2020, Pukul 13.39 WIB).
} 
melakukan berbagai aktifitas misalnya, berkomunikasi dengan orang lain, memesan makanan, belanja online, dan berbagai aktifitas lainnya.

Dalam berbagai sisi kecanggihan teknologi memberikan dampak positif dan negative. Tidak dapat terhitung lagi berapa banyak keuntungan atau manfaat yang diperoleh dari kecanggihan teknologi, mulai dari mampu menghasilkan uang, mendapatkan keperluan logistic dengan mudah, dan memudahkan komunikasi jarak jauh tanpa harus berlamalama menunggu balasan dari seseorang yang kita hubungi dengan catatan, jika ingin menghubungi seseorang tersebut harus terkoneksi dengan jaringan internet atau memiliki kuota data dan pulsa. Dampak dari sisi negative jika kita tidak bijak dalam menggunakan teknologi, hal tersebut bisa menyebabkan berbagai kerugian bagi banyak pihak. Baik kita yang menjadi korban penyalahgunaan tersebut atau kita yang melakukan penyalahgunaan dalam teknologi ini . Sisi negative yang ditimbulkan dalam penggunaan teknologi ini adalah orang-orang yang tidak bertanggungjawab mencari keuntungan untuk dirinya sendiri tanpa mengetahui akibat dari perbuatan mereka tersebut. Oleh karena itu, diperlukannya Undang-undang yang mengatur dalam pelaksanaan penggunaan teknologi untuk melindungi serta memberi arahan dalam menggunakan teknologi agar tidak menjadi korban kejahatan, serta meminimalisir terjadinya kejahatan di dunia maya (Cyber Crime).

Undang-undang Republik Indonesia Nomor 19 tahun 2016 tentang perubahan atas Undang-undang nomor 11 tahun 2008 tentang informasi dan transaksi elektronik. Undang-undang tersebut mengatur beberapa akibat hukum yang akan didapatkan kepada pelaku kejahatan yang melakukan kejahatan dunia maya (Cyber Crime). Salah satu contoh dalam skala besar kejahatan dunia maya seperti, akses jaringan terorisme, maksud dari akses jaringan terorisme ini adalah seperti suatu perkumpulan orang-orang yang terjaring dalam suatu situs atau web gelap yang dimana mereka memiliki satu visi dan misi yang sama, yang salah dalam memahami arti jihad dan mengatasnamakan Islam dan hendak meluncurkan suatu tindakan yang mengakibatkan kerugian bagi banyak pihak atau kejahatan genosida. Syukurnya situs tersebut telah diblokir oleh pihak kominfo. Dalam sekala kecil, banyak sekali kejahatan yang menyangkut-pautkan atas nama pribadi, seperti penipuan mengatasnamakan seseorang yang tidak melakukan hal tersebut, pencemaran nama baik, perjudian, tindak asusila, ujaran kebencian, akun fake, akun hacked, dan lain-lain sebagainya. Biasanya mereka melakukan hal tersebut dalam bentuk situs web berbentuk aplikasi yang banyak digunakan masyarakat modern saat ini seperti, Facebook, Askfkm, Twitter, Instagram, Blogger, Plurk, dan lain-lain. Tidak semua pemakai akun dapat melakukan penghapusan terhadap akunnya sendiri sehingga banyak sekali akun yang diiarkan begitu saja yang mengakibatkan akun tersebut rentan untuk disalahgunakan oleh pihak tertentu, dengan kehadiran jasa hapus akun ini akan memberikan rasa aman dari pengguna akun.

\section{HASIL DAN PEMBAHASAN}

Berdasarkan tulisan yang dimuat dalam jurnal ilmiah yang berjudul "Perlindungan Hukum Terhadap Korban Kejahatan Cyber Crime Di Indonesia" dinyatakan bahwa pada tahun 2004 Indonesia menduduki peringkat pertama dalam kasus kejahatan dunia maya, dan perkara tersebut diperkirakan termasuk dalam kasus yang berat dari Amerika Serikat. ${ }^{3}$ Dalam hal ini masyarakat dituntut untuk memiliki pengetahuan apa yang dimaksud dengan kejahatan dunia maya (Cyber Crime) serta berbagai pengetahuan yang terkait dengan kejahatan dunia maya tersebut, berikut uraiannya.

\section{Cyber Crime}

\section{Pengertian Cyber Crime}

Cyber Crime merupakan gabungan dari dua kata yakni, cyber dan crime dimana arti dari cyber itu sendiri adalah dunia maya atau internet, dan crime itu sendiri kejahatan. ${ }^{4}$ Di dalam buku karya Budi Raharjo yang berjudul "Memahami Teknologi Informasi" ia mendefinisikan bahwa cybercrime itu adalah sebagai perbuatan melanggar hukum yang memanfaatkan teknologi computer yang berbasis pada kecanggihan perkembangan teknologi internet. ${ }^{5}$ Beberapa literatur mengatakan, cybercrime sering diidentikkan sebagai computer crime. Dalam buku karya Andi Hamzah yang bejudul " Aspek-aspek Pidana di Bidang Komputer" mendefiniskan kejahatan di bidang computer secara umum dapat dartikan sebagai penggunaan computer secara illegal. Cyber Crime adalah perbuatan criminal yang dilakukan dengan menggunakan teknologi computer sebagai alat kejahatan utama. Dengan kata lain, cybercrime yaitu kejahatan yang memanfaatkan perkembangan teknologi computer khususnya internet. Dengan demikian

\footnotetext{
${ }^{3}$ Dheny Wahyudi, Perlindungan Hukum Terhadap Korban Kejahatan Cyber Crime Di Indonesia, Jurnal Ilmu Hukum,
} hlm. 100 .

${ }^{4}$ Agus Rahardjo, Cybercrime Pemahaman dan Upaya Pencegahan Kejahatan Berteknologi, PT. Citra Aditya Bakti, Bandung, 2002.

${ }^{5}$ Budi Raharjo, Memahami Teknologi Informasi, Elexmedia Komputindo, Jakarta, 2002, hlm. 23. 
cybercrime didefinisikan sebagai perbuatan melanggar hukum yang memanfaatkan teknologi computer berbasis pada kecanggihan dan perkembangan teknologi internet. ${ }^{6}$

\section{Bentuk Cyber Crime}

1. Unauthorized Access to Computer System and Service.

Kejahatan ini dilakukan dengan memasuki/menyusup ke dalam suatu sistem jaringan komputer secara tidak sah, tanpa ijin atau tanpa sepengetahuan dari pemilik jaringan komputer yang dimasukinya. Motifnya adalah bermacam-macam antara lain adalah sabotase, pencurian data dan sebagainya.

2. Illegal Contens.

Kejahatan ini dilakukan dengan memasukkan data atau informasi ke internet tentang sesuatu yang tidak benar, tidak etis dan dapt dianggap melanggar hukum atau mengganggu ketertiban umum. Contoh yang termasuk kejahatan jenis ini adalah pornografi, pemuatan berita bohong, termasuk juga delik-delik politik dapat dimasukkan kedalam kategorgi ini bila menggunakan ruang cyber.

3. Data Forgery.

Yaitu merupakan kejahatan dengan cara memalsukan data pada dokumen-dokumen penting yang tersimpan sebagai dokumen melalui internet.

4. Cyber Espionage.

Yaitu merupakan kejahatan yang memanfaatkan jaringan internet untuk melakukan kegiatan mata-mata terhadap pihak lainn, dengan cara memasuki sistem jaringan komputer (computer network system) pihak sasaran. Kejahatan ini biasanya ditujukan terhadap saingan bisnis yang dokumen atau datanya tersimpan dalam suatu sistem yang computeraized.

5. Cyber Sabotage and Extortion.

Kejahatan ini dilakukan dengan membuat gangguan, perusakan atau penghancuran terhadap suatu data, program komputer atau sistem jaringan komputer yang terhubung ke internet. Biasanya kejahatan ini dilakukan dengan menyusupkan suatu virus komputer atau program tertentu sehingga data program komputer atau sistem jaringan tidak dapat digunakan lagi, tidak berjalan sebagaimana mestinya atau berjalan sebagaimana yang dikehendaki oleh pelaku. Kejahatan ini juga sering disebut dengan kejahatan cyber terrorism.

6. Offence Againts Intellectual Property.

Kejahatan ini ditujukan terhadap HKI atau Hak kekayaan intelektual yang dimiliki pihak lain di internet. Sebagai contoh, meniru tampilan web suatu situs tertentu, penyiaran rahasia dagang yang merupakan rahasia dagang orang lain.

7. Infringements of Privacy.

Kejahatan ini ditujukan terhadap informasi seseorang yang merupakan hal yang sangat pribadi dan rahasia. Kejahatan simpan secara computerized. Yang apabila diketahui orang lain maka dapat merupakan korban secara materiil atau immateriil, seperti nomor PIN ATM, nomor kartu kredit dan sebaginya. ${ }^{7}$

\section{Pengaturan Cyber Crime di Indonesia}

Negara Indonesia belum memiliki Undang-Undang khusus untuk mengatur Cyber Crime. Namun, ada beberapa aturan hukum yang berlaku di Indonesia yang bisa dijadikan patokan untuk menyelesaikan permasalahn kejahatan dunia maya antara lain $:^{8}$

1. Kitab Undang-Undang Hukum Pidan (KUHP)

Pasal-pasal didalam KUHP biasanya digunakan lebih dari satu Pasal karena melibatkan beberapa perbuatan sekaligus pasal-pasal yang dapat dikenakan dalam KUHP pada cyber crime yaitu :

a. Pasal 362 KUHP yang dikenakan untuk kasus carding dimana pelaku mencuri nomor kartu kredit milik orang lain walaupun tidak secara fisik karena hanya nomor kartunya saja yang diambil dengan menggunakan software card generator di Internet untuk melakukan transaksi di e-commerce. Setelah dilakukan transaksi dan barang dikirimkan, kemudian penjual yang ingin mencairkan uangnya di bank ternyata ditolak karena pemilik kartu bukanlah orang yang melakukan transaksi.

b. Pasal 378 KUHP dapat dikenakan untuk penipuan dengan seolah-olah menawarkan dan menjual suatu produk atau barang dengan memasang iklan di salah satu website sehingga sehingga orang tertarik untuk membelinya lalu mengirimkan uang kepada pemasang iklan. Tetapi, pada kenyataannya, barang tersebut tidak ada. Hal

\footnotetext{
${ }^{6}$ H Sofwan Jannah, dan M Naufal, Penegakan Hukum Cyber Crime Ditinjau Dari Hukum Positif dan Hukum Islam, Yogyakarta, Al-Mawarid, Volume XII No.1, 2012, hlm.70.

${ }^{7}$ Ibid, hlm 71-73.

${ }^{8}$ Deris Setiawan, Sistem Keamanan Komputer, PT Elex Media Komputindo, Jakarta, 2005, hlm. 70-77.
} 
tersebut diketahui setelah uang dikirimkan dan barang yang dipesankan tidak datang sehingga pembeli tersebut menjadi tertipu.

c. Pasal 335 KUHP dapat dikenakan untuk kasus pengancaman dan pemerasan yang dilakukan melalui e-mail yang dikirimkan oleh pelaku untuk memaksa korban melakukan sesuatu sesuai dengan apa yang diinginkan oleh pelaku dan jika tidak dilaksanakan akan membawa dampak yang membahayakan. Hal ini biasanya dilakukan karena pelaku mengetahui rahasia korban.

d. Pasal 311 KUHP dapat dikenakan untuk kasus pencemaran nama baik dengan menggunakan media internet. Modusnya adalah pelaku menyebarkan email kepada teman-teman korban tentang suatu meiling list sehingga banyak orang mengetahui cerita tersebut.

e. Pasal 303 KUHP dapat dikenakan untuk menjerat permainan judi yang dilakukan secara online di internet dengan penyelenggaraan di Indonesia.

f. Pasal 282 KUHP dapat dikenakan untuk penyebaran pornografi maupun website porno yang banyak beredar dan mudah diakses di Internet. Walaupun berbahasa Indonesia sangat sulit sekali untuk menindak pelakunya karena mereka melakukan pendaftaran domain tersebut di luarnegeri diamana pornografi yang menampilakan orang dewasa bukan merupakan hal yang terlarang atau illegal.

g. Pasal 282 dan 311 KUHP dapat dikenakan untuk kasus penyebaran foto atau film yang bersifat pribadi seseorang yang vulgar di Internet, misalnya kasus-kasus video porno para mahasiswa, pekerja atau pejabat public.

h. Pasal 378 dan 262 KUHP dapat dikenakan pada kasus carding, karena pelaku melakukan penipuan seolah-olah ingin membeli suatu barang dan membayar dengan kartu kreditnya yang nomor kartu kreditnya merupakan curian.

i. Pasal 406 KUHP dapat dikenakan pada kasus deface atau hacking yang membuat system milik orang lain, seperti website atau program menjadi tidak berfungsi atau dapat digunakan sebagaimana mestinya.

2. Pengaturan Tindak Pidana Siber Materil di Indonesia

Berdasarkan Instrumen PBB, maka pengaturan tindak pidana siber di Indonesia juga dapat dilihat dalam arti luas dan arti sempit. Secara luas, tindak pidana siber ialah semua tindak pidana yang menggunakan sarana atau dengan bantuan sistem elektronik. Itu artinya semua tindak pidana konvensional dalam Kitab Undang-Undang Hukum Pidana ("KUHP") sepanjang dengan menggunakan bantuan atau sarana sistem elektronik seperti pembunuhan, perdagangan orang, dapat termasuk dalam kategori tindak pidana siber dalam arti luas. Demikian juga tindak pidana dalam Undang-Undang Nomor 3 Tahun 2011 tentang Transfer Dana ("UU 3/2011") maupun tindak pidana perbankan serta tindak pidana pencucian uang dalam Undang-Undang Nomor 8 Tahun 2010 tentang Pencegahan dan Pemberantasan Tindak Pidana Pencucian Uang ("UU TPPU”).

Akan tetapi, dalam pengertian yang lebih sempit, pengaturan tindak pidana siber diatur dalam UndangUndang Nomor 11 Tahun 2008 tentang Informasi dan Transaksi Elektronik ("UU ITE") sebagaimana yang telah diubah oleh Undang-Undang Nomor 19 Tahun 2016 tentang Perubahan Atas Undang-Undang Nomor 11 Tahun 2008 tentang Informasi dan Transaksi Elektronik ("UU 19/2016") sama halnya seperti Convention on Cybercrimes, UU ITE juga tidak memberikan definisi mengenai cybercrimes, tetapi membaginya menjadi beberapa pengelompokkan yang mengacu pada Convention on Cybercrimes (Sitompul, 2012):

a. Tindak pidana yang berhubungan dengan aktivitas illegal, yaitu:

1) Distribusi atau penyebaran, transmisi, dapat diaksesnya konten illegal, yang terdiri dari:

a) Kesusilaan (Pasal 27 ayat (1) UU ITE);

b) Perjudian (Pasal 27 ayat (2) UU ITE);

c) penghinaan dan/atau pencemaran nama baik (Pasal 27 ayat (3) UU ITE);

d) pemerasan dan/atau pengancaman (Pasal 27 ayat (4) UU ITE);

e) berita bohong yang menyesatkan dan merugikan konsumen (Pasal 28 ayat (1) UU ITE);

f) menimbulkan rasa kebencian berdasarkan SARA (Pasal 28 ayat (2) UU ITE);

g) mengirimkan informasi yang berisi ancaman kekerasan atau menakut-nakuti yang ditujukan secara pribadi (Pasal 29 UU ITE);

2) dengan cara apapun melakukan akses illegal (Pasal 30 UU ITE);

3) intersepsi atau penyadapan illegal terhadap informasi atau dokumen elektronik dan Sistem Elektronik (Pasal 31 UU 19/2016);

b. Tindak pidana yang berhubungan dengan gangguan (interferensi), yaitu:

1) Gangguan terhadap Informasi atau Dokumen Elektronik (data interference - Pasal 32 UU ITE);

2) Gangguan terhadap Sistem Elektronik (system interference -Pasal 33 UU ITE);

c. Tindak pidana memfasilitasi perbuatan yang dilarang (Pasal 34 UU ITE);

d. Tindak pidana pemalsuan informasi atau dokumen elektronik (Pasal 35 UU ITE);

e. Tindak pidana tambahan (accessoir Pasal 36 UU ITE); dan 
f. Perberatan-perberatan terhadap ancaman pidana (Pasal 52 UU ITE).

3. Pengaturan Tindak Pidana Siber Formil di Indonesia

Selain mengatur tindak pidana siber materil, UU ITE mengatur tindak pidana siber formil, khususnya dalam bidang penyidikan. Pasal 42 UU ITE mengatur bahwa penyidikan terhadap tindak pidana dalam UU ITE dilakukan berdasarkan ketentuan dalam Undang-Undang Nomor 8 Tahun 1981 tentang Hukum Acara Pidana ("KUHAP") dan ketentuan dalam UU ITE. Artinya, ketentuan penyidikan dalam KUHAP tetap berlaku sepanjang tidak diatur lain dalam UU ITE. Kekhususan UU ITE dalam penyidikan antara lain :

a. Penyidik yang menangani tindak pidana siber ialah dari instansi Kepolisian Negara RI atau Pejabat Pegawai Negeri Sipil ("PPNS") Kementerian Komunikasi dan Informatika;

b. Penyidikan dilakukan dengan memperhatikan perlindungan terhadap privasi, kerahasiaan, kelancaran layanan publik, integritas data, atau keutuhan data;

c. Penggeledahan dan/atau penyitaan terhadap sistem elektronik yang terkait dengan dugaan tindak pidana harus dilakukan sesuai dengan ketentuan hukum acara pidana;

d. Dalam melakukan penggeledahan dan/atau penyitaan sistem elektronik, penyidik wajib menjaga terpeliharanya kepentingan pelayanan umum. ${ }^{9}$

Pengetahuan kejahatan dunia maya (Cyber Crime) sangat dibutuhkan untuk menambah wawasan bagi masyarakat, Adapun tujuan utama mempelajari ilmu kejahatan dunia maya (Cyber Crime) bukan untuk memperaktekkannya dalam kehidupan sehari-hari melainkan sebagai bekal ilmu bahwa perbuatan tersebut adalah perbuatan yang telarang. Minimnya pengetahuan terhadap kejahatan dunia maya (Cyber Crime) memeberikan berbagai dampak, tentunya yang sangat terlihat yaitu, dampak negative karena tidak mengetahui jika hal tersebut terjadi bisa mengakibatkan kerugian bagi orang lain termasuk diri sendiri. Maka dari itu diperlukannya solusi jika terjadi hal yang tidak diinginkan tersebut (Cyber Crime). Salah satunya melalui. jasa hapus akun sebagai sorotan ataupun bahasan pokok dalam tulisan ini. Jasa hapus akun adalah salah satu sarana jasa yang dapat digunakan untuk membantu korban kejahatan untuk menghapus suatu akun yang dipermasalahkan tersebut dalam sekala yang kecil. Seperti contoh, jika ada akun sosial media seseorang seperti Facebook, yang dihack maka jasa hapus akun ini dapat membantu menghapus akun tersebut secara permanent sesuai dengan syarat dan ketentuan yang berlaku. Namun, tidak dapat membantu mengembalikan akun Facebook tersebut, karena system yang berbeda. Dilihat dari system dan mekanismenya, tidak banyak yang mengetahui mengenai jasa hapus akun . Karena, masih terdengar baru dan masih asing di telinga masyarakat, maka dari itu akan di bahas secara gamblang mengenai jasa hapus akun ini.

\section{Jasa Hapus Akun \\ Sejarah Jasa Hapus Akun}

Tidak diketahui dengan pasti tahun, tanggal, dan bulan berapa jasa hapus akun ini mulai berdiri. Dikarenakan kurangnya sumber yang ilmiah, hanya berdasar pembicaraan terhadap sesama subjek yang membuka jasa hapus akun. Meski kendati demikian, penulis mengutip dalam tulisan skripsi seorang mahasiswa yang membahas tentang " Tinjauan Hukum Islam Tentang Jual Beli Jasa Hapus Akun Di Media Sosial Facebook (Studi Kasus Di Toko Online Shop@Ollshop_Lampung)" dikatakan bahwa, jasa hapus akun ini telah berjalan sejak tahun $2018{ }^{10}$. Jasa ini dibuat oleh beberapa orang untuk membantu kaum muslimin yang mengalami masalah terhadap akunnya. Seperti, di hack, akun fake, foto lawas yang mengumbar aurat, penipuan, pencemaran nama baik. Jasa ini bisa menghapus akun tanpa menggunakan email dan password, dengan rentang waktu terhapus yang berbeda-beda. Melihat dari hal tersebut, beberapa orang yang tidak diketahui dengan pasti identitasnya membuka jasa hapus akun ini, kemudian disebarluaskan hingga memasuki tahun kedua dalam 2020 ini. Meski banyak yang masih awam terhadap jasa hapus akun ini namun, penulis berusaha untuk memperkenalkan jasa ini, untuk membantu masyarakat yang membutuhkan dan masih dalam tahap proses memperkenalkan jasa hapus akun.

\section{Keberadaan Jasa Hapus Akun}

Keberadaan Jasa Hapus Akun baru-baru ini tahun 2020 sedikit menjadi sorotan dalam lingkungan aktivis dakwah sunnah, khususnya mereka para followers akun-akun sosial media dakwah sunnah. Jasa ini menjadi sorotan di kalangan dakwah sunnah karena, mereka sudah mengetahui bagaiamana hukum dari mengupload foto. Jadi, mereka ingin sekali menggunakan jasa ini, untuk menghapus foto-foto mereka baik mengumbar aurat ataupun tidak, dikhawatirkan bisa menyebakan dosa jariyyah atau disalahgunkan oleh pihak lain dimana akun tersebut sudah tidak

\footnotetext{
9 https://www.hukumonline.com/klinik/detail/ulasan/c15960/landasan-hukum-penanganan-icybercrime-i-di-indonesia (diakses pada tanggal 02 Agustus 2020, Pukul 14.30 WIB).

${ }^{10}$ Novita Sari, Tinjauan Hukum Islam Tentang Jual Beli Jasa Hapus Akun Di Media Sosial Facebook (Studi Kasus Di Toko Online Shop @Ollshop_Lampung), 2019, hlm. 6.
} 
bisa dibuka lagi alias lupa email dan password. Kini jasa hapus akun telah banyak dijumpai diberbagai sosial media, meski dahulu hanya segelintir orang saja yang mengetahui dan menggunakan jasa ini. Jasa hapus akun juga telah membuka bimbel secara terbuka dan tidak tertutup lagi, bahkan ada yang membuka bimbelnya dengan gratis tanpa dipungut biaya apapun hanya bermodalkan kuota dan akses jaringan internet serta akun yang akan dihapus. Pada tahun 2018-2019 kala itu, tidak banyak orang yang membuka jasa hapus akun, dikarenakan system bimbel yang masih tertutup, hanya untuk orang-orang tertentu saja bisa mengikuti bimbel ini, dikarenkan beberapa hal tertentu seperti, ilmu yang tidak boleh diberikan oleh orang yang tidak dapat mempertanggungjawabkannya. Karena, ilmu tersebut jika disalahkgunakan akan memberikan kerugian terhadap orang lain demi keuntungan pribadi dan berbanding terbalik dari tujuan utama dalam membuka jasa hapus akun ini yakni membantu orang yang mengalami masalah terhadap akunnya. Seiring berjalannya waktu jasa hapus akun mulai dikenal masyarakat, karena membayar beberapa tokoh public dan beberapa influencer dalam mempromosikan jasa hapus akun ini.

\section{Manfaat Jasa Hapus Akun}

Banyak sekali dampak positif yang didapatkan dari munculnya Jasa Hapus Akun ini, Adapun manfaat yang dapat diperoleh dari jasa hapus akun seperti :

1. Menghapus akun sosial media lawas dimana terdapat foto yang mengumbar aurat ataupun tidak.

2. Menghapus akun sosial media karena sudah lama tidak terpakai dan lupa kata sandi beserta passwordnya.

3. Mengahpus akun sosial media saudara yang telah meninggal dunia karena khawatir laman tersebut terus dikunjungi dan membuat keluarga resah.

4. Menghapus akun sosial media karena di hack.

5. Menghapus akun sosial media karena identitas kita dipakai oleh akun fake.

6. Menghapus akun sosial media karena dijadikan akun untuk penipuan atau dapat merugikan orang banyak.

Ada banyak sekali manfaat yang bisa kita dapatkan dari jasa hapus akun ini terlebih dari tidak hanya manfaat secara perbuatan membantu orang lain saja, namun kita juga bisa mendapatkan keuntungan berupa upah dari jasa hapus akun tersebut dengan tarif sesuai kesepakatan antara customer dan pelaku usaha.

\section{Permasalahan Yang Dihadapi Dalam Jasa Hapus Akun}

Setiap jenis usaha dalam melakukan sesuatu yang baik, pasti kita mendapatkan berbagai rintangan dalam melakukan proses tersebut, sama dengan halnya dalam jasa hapus akun ini. Berbagai pengalaman yang penulis dapatkan dalam menghadapi customer dalam bertransaksi untuk menggunakan jasa hapus akun ini. Adapun permasalahan yang dihadapi dalam jasa hpus akun, yaitu :

1. Customer yang tidak ingin membayar setelah akunnya terhapus. Karena, pada akadnya customer akan membayar jasanya jika akunnya telah terhapus secara permanent. Namun, ada beberapa customer yang tidak memenuhi janjinya setelah akunnya terhapus. Padahal sebelumnya sudah ada kesepakatan antara kedua belah pihak dan sudah sesuai dengan asas-asas hukum, keberlakuan suatu asas merupakan kepastian dan oleh karena itu ketika ia diberlakukan untuk memecahkan masalah, tidak ada suatu keraguan atas kebenarannya dan oleh karena itu ia dapat dijadikan pengawal di dalam memutuskan masalah, ${ }^{11}$

2. Customer mengatakan jasa ini merupakan komplotan penipuan, dikarenakan ada beberapa syarat yang dimintai seperti , identitas, nomor hp aktif, tanggal lahir customer. Namun, tidak lain hal ini merupakan salah satu dari mekanisme untuk menghapus akun sosial media yang diinginkan. Meski identitas dimintai hal itu tidak lain adalah sebagai syarat dalam menghapus akun, pelaku usaha tetap menjaga privasi customer.

3. Customer tidak mengetahui jika jasa ini berbayar, karena kesalahan dari beberapa jasa yang tidak melakukan akad terlebih dahulu. Seperti memberitahu jika hendak menggunakan jasa ini akan dikenakan tarif tertentu.

4. Akun sosial media sulit terhapus dikarenakan pandemic covid-19 membuat laporan menghapus akun lamban diproses.

5. Akun sosial media tidak bisa terhapus karena, beberapa ketentuan syarat yang tidak dapat terpenuhi.

6. Tidak mampu mengembalikan akun sosial media yang bermasalah, hanya dapat dihapus.

Itulah beberapa permasalahan yang dapat dirangkup selama penulis menjalani bisnis jasa hapus akun. Dalam hal ini perlu dikaji lebih mendalam lagi, untuk menindaklanjuti permasalahan jasa hapus akun ini dari segi hukum. Sebelum membahas permasalahan lebih jauh, ada baiknya kita memahami terlebih dahulu apa itu pengertian dari jual beli online.

${ }^{11}$ Supeno dkk, Kedudukan Asas Hukum dalam Penyelesaian Sengketa Melalui Arbitrase Berdasarkan Undang-Undang Nomor 30 Tahun 1999, Jurnal Wajah Hukum, Volume 3(1), hal. 55. 
Mengutip dari Kamus Besar Bahasa Indonesia, jual beli adalah persetujuan saling mengikat antara penjual, yakni pihak yang menyerahkan barang, dan pembeli sebagai pihak yang membayar harga barang yang dijual. ${ }^{12}$ Menurut Rahmat Syafe'i, secara bahasa jual beli adalah pertukaran sesuatu dengan sesuatu yang lain. ${ }^{13}$ Kata Online terdiri dari dua kata, yaitu On (Inggris) yang berarti hidup atau didalam, dan Line (Inggris) yang berarti garis, lintasan, saluran atau jaringan. ${ }^{14}$ Dari pengertian-pengertian tersebut, maka dapat disimpulkan bahwa jual beli online adalah persetujuan saling mengikat melalui internet antara penjual sebagai pihak yang menjual barang dan pembeli sebagai pihak yang membayar harga barang yang dijual. Jual beli secara online menerapkan sistem jual beli di internet. Tidak ada kontak secara langsung antara penjual dan pembeli. Jual beli dilakukan melalui suatu jaringan yang terkoneksi dengan menggunakan handphone, komputer, tablet, dan lain-lain. ${ }^{15}$

Melihat dari pengertian dapat diambil pelajaran bahwa jual beli online tersebut ada hubungan yang mengikat antara pembeli dan penjual. Termasuk dalam jasa hapus akun ini, adanya hubungan hukum antara pelaku usaha jasa dengan customer yang meminta jasa. Dimana antara pelaku usaha jasa harus saling memenuhi hak dan kewajibannya masing-masing. Dan juga telah ditegaskan dalam Pasal 1313 KUHPerdata, yaitu: ${ }^{16}$ Suatu perbuatan dengan mana satu orang atau lebih mengikatkan dirinya terhadap satu orang lain atau lebih. Sebelum mengikatkan diri kepada orang lain, kita harus memahami bahwa untuk melakukan suatu perjanjian ada beberapa syarat yang harus dipenuhi yang termuat dalam Pasal 1320 KUHPerdata Untuk sahnya suatu perjanjian diperlukan empat syarat: ${ }^{17}$

1. Sepakat mereka yang mengikatkan dirinya;

2. Kecakapan untuk membuat suatu perikatan;

3. Suatu hal tertentu;

4. Suatu sebab yang halal.

Dilihat dari permasalahan yang dihadapi dalam menjalankan bisnis jasa hapus akun tersebut, maka dapat dimengerti bahwa banyak sekali customer dan pelaku usaha yang belum memiliki pengetahuan mengenai bagaimana melakukan suatu perjanjian secara benar yang bersifat umum dan tidak sesuai dengan aturan hukum yang berlaku. Maka dari itu untuk menghindari dari beberapa hal yang akan mengakibatkan kerugian dalam bertransaksi menggunakan jasa hapus akun, ada baiknya dipahami terlebih dahulu syarat, dan mekanisme yang harus diikuti jika ingin menggunakan jasa ini dalam mengantisipasi permasalahan terulang kembali terjadi dan menyiapkan bekal ilmu mengenai bagaimana cara bertransaksi secara online dengan baik dan benar berdasarkan perjanjian yang dibuat. Dalam konteks ini konsumen tidak akan ragu menyerahkan akun yang ada untuk dilakukan penghapusan dan segala sesuatu yang berkaitan dengan data pribadi harus disampaikan secara jujur oleh pelaku usaha untuk menghindari kejahatan yang mungkin akan dilakukan oleh oknum pelaku usaha jasa akun., di sisi lain pelaku usaha jasa akun harus mempertanggungjawabkan apa yang telah dikerjakan sesuai dengan batasan yang telah dituangkan dalam perjanjian kedua belah pihak. Dengan adanya perjanjian kedua belah pihak dapat menuntut jika salah satu pihak wanprestasi, baik pelaku usaha maupun konsumen. Selain itu konsumen juga dapat menuntut berdasarkan pasal 8 Undang-Undang Nomor 8 Tahun 1999 Tentang Perlindungan Konsumen, bahwa pelaku usaha dilarang memproduksi atau memperdagangkan barang/atau jasa yang tidak sesuai dengan janji yang dinyatakan dalam label, etiket, keterangan, iklan atau promosi penjualan barang dana tau jasa. ${ }^{18}$

\section{SIMPULAN}

Jasa hapus akun merupakan salah satu solusi yang dapat ditempuh dalam menangani permasalahan terjadinya kejahatan penggunaan akun secara illegal di media sosial, hadirnya jasa hapus akun ini akan memberikan manfaat dalam kehidupan bermasyarakat, karena tidak dapat kita pungkiri teknologi terus berkembang dari zaman ke zamannya dan tingkat kejahatan di dunia mayapun semakin marak terjadi,jasa hapus akun merupakan upaya untuk pencegahan sebelum kita menjadi korban kejahatan dunia maya (Cyber Crime), akan tetapi belum banyak masyarakat yang mengetahui keberadaan jasa hapus akun, selain itu para pengguna jasa akun (konsumen) belum memahami bahwa antara pelaku usaha jasa akun dan konsumen terikat perjanjian yang menharuskan masing-masing pihak

${ }^{12}$ Departemen Pendidikan Nasional, Kamus Besar Bahasa Indonesia Pusat Bahasa, Edisi IV Cet. 1, PT Gramedia Pustaka, Jakarta, hlm. 589.

${ }^{13}$ Rahmat Syafe`i, Fiqh Muamalah, hlm. 73.

${ }^{14}$ Disa Nusia Nisirna Tinjauan Hukum Islam Terhadap Jual Beli Online Dan Relevansinya Terhadap Undang-Undang Perlindungan Konsumen, Fakultas Syariah dan Hukum Uin Alauddin Makassar, Makassar, 2015, hlm. 48.

${ }^{15}$ Ibid.

${ }^{16}$ Republik Indonesia, Kitab Undang-undang Hukum Perdata, Pasal 1313.

${ }^{17}$ Republik Indonesia, Kitab Undang-Undang Hukum Perdata, Pasal 1320.

${ }^{18}$ Supeno, Ganti Kerugian Berdasarkan Perjanjian Antara Pengembang Perumahan dengan Konsumen di Atas Tanah rawan Banjir, Jurnal Wajah Hukum Volume 4 (1), April 2020, hal.139. 
Supeno, Fachruddin Razi dan Putri Anelia Anmas, Jasa Hapus Akun dan Permasalahannya Ditinjau Dari Kekuatan Mengikat Perjanjian Antara Konsumen dengan Pelaku Bisnis Jasa Hapus Akun

melaksanakan prestasinya sesuai dengan isi perjanjian, oleh karena itu dituntut konsumen memahami dengan baik hakekat dari suatu perjanjian walaupun dilakukan melalui media elektronik.

\section{DAFTAR PUSTAKA}

Buku

Departemen Pendidikan Nasional, Kamus Besar Bahasa Indonesia Pusat Bahasa, Edisi IV Cet. 1, PT Gramedia Pustaka, Jakarta.

Rahardjo, Agus, Cybercrime Pemahaman dan Upaya Pencegahan Kejahatan Berteknologi, PT. Citra Aditya Bakti, Bandung, 2002.

Raharjo, Budi, Memahami Teknologi Informasi, Elexmedia Komputindo, Jakarta, 2002.

Setiawan, Deris, Sistem Keamanan Komputer, PT Elex Media Komputindo, Jakarta, 2005.

Syfa'i, Rahmat, Fiqh Muamalah.

\section{Jurnal Ilmiah}

Jannah, H Sofwan, dan M Naufal, Penegakan Hukum Cyber Crime Ditinjau Dari Hukum Positif dan Hukum Islam, Yogyakarta, Al-Mawarid, Volume XII No.1, 2012.

Nisirna, Disa Nusia, Tinjauan Hukum Islam Terhadap Jual Beli Online Dan Relevansinya Terhadap Undang-Undang Perlindungan Konsumen, Fakultas Syariah dan Hukum Uin Alauddin Makassar, Makassar, 2015.

Sari, Novita, Tinjauan Hukum Islam Tentang Jual Beli Jasa Hapus Akun Di Media Sosial Facebook (Studi Kasus Di Toko Online Shop @Ollshop_Lampung), Skripsi, 2019.

Supeno dkk, Kedudukan Asas Hukum dalam Penyelesaian Sengketa Melalui Arbitrase Berdasarkan Undang-Undang Nomor 30 Tahun 1999, Jurnal Wajah Hukum, 3 (1).

............., Ganti Kerugian Berdasarkan Perjanjian Antara Pengembang Perumahan dengan Konsumen di Atas Tanah rawan Banjir, Jurnal Wajah Hukum Volume 4 (1), April 2020

Wahyudi, Dheny, Perlindungan Hukum Terhadap Korban Kejahatan Cyber Crime Di Indonesia, Jurnal Ilmu Hukum.

\section{Peraturan Perundang-undangan}

Republik Indonesia, Kitab Undang-undang Hukum Perdata.

Republik Indonesia, Undang-Undang Nomor 19 Tahun 2016 Tentang Perubahan Atas Undang-Undang Nomor 11

Tahun 2008 Tentang Informasi dan Transaksi (Lembaran Negara Republik Indonesia Tahun 2016 Nomor 251).

\section{Website}

https://id.wikipedia.org/wiki/Teknologi

https://www.hukumonline.com/klinik/detail/ulasan/cl5960/landasan-hukum-penanganan-icybercrime-i-di-indonesia. 